ENSAYO

\title{
EL CAPÍTULO IX DEL PRIMER QUIJOTE
}

\author{
Jorge Guzmán
}

El Capítulo IX del Quijote — sostiene Jorge Guzmán en este artículo- es el momento textual en que aparece por primera vez el "verdadero" autor del libro, Cide Hamete Benengeli. Este autor es una personificación de una característica de toda imitación de vidas humanas: que carecen de la posibilidad de negar cabalmente, es decir, carecen de un "no" pleno y por lo tanto no rigen en ellas los principios lógicos. Por eso, para controlar su narración, Cervantes inventó el narrador personal. Pero no bastó el invento. Las incoherencias e inverosimilitudes siguieron en el Quijote, y siguen en toda novela.

Jorge GuZmán (Santiago, 1930). Ph. D. en literatura, State University of Iowa. Fue profesor de literatura en la Universidad de Chile entre 1961 y 1995 y profesor visitante durante algunos períodos en varias universidades norteamericanas (Indiana University, University of Illinois, Iowa y Michigan). Autor de los ensayos Una constante didáctico-moral del Libro de buen amor (1963; 2da edición, DEH, 1980); Diferencias latinoamericanas (Santiago, Centro de Estudios Humanísticos, 1984); Contra el secreto profesional: lectura mestiza de César Vallejo (Santiago, Editorial Universitaria, 1991), y "Tahuashando": Lectura mestiza de César Vallejo (segunda edición de Contra el secreto profesional, con adiciones y correcciones, Santiago, LOM, 2001). Entre sus novelas están Job-boj (Seix Barral, 1968, 1970). Su novela Ay, mama Inés (Santiago: Editorial Andrés Bello, 1993, 1995) obtuvo en 1994, entre otros, el Premio Academia de la Lengua (novela), 1994. En 1999 publicó La ley del gallinero (Editorial Sudamericana, 1999), y en 2003, Cuando florece la higuera (Barcelona: Debate), por la cual recibió el Premio Jaén de Novela 2003, patrocinado por la Fundación Caja de Granada.

Estudios Públicos, 100 (primavera 2005). 


\section{Ni me lo hubieran pedido como antiguo cervantista o "quijotista",} no habría aceptado la invitación a colaborar en este número de conmemoración de la fecha oficial de la primera edición del Quijote, 1605 (que realmente se imprimió a finales de 1604). Demasiada agua ha pasado bajo mis puentes desde que me alejé de la lectura técnica de textos como ejercicio personal y cambié la profesión de académico por el juego de contador de historias. Y mucha más agua, por cierto, desde, pongamos, los dichos de don Marcelino Menéndez y Pelayo sobre el tema cervantino hasta los de Félix Martínez Bonati en su definitiva lectura fenomenológica de la novela (Don Quijote y la poética de la novela, 2004). Mirando desde mi estancia actual de escribidor de ficciones, creo que pueden ser de algún interés, especialmente para novelistas que principian, algunas consideraciones sobre un momento del desarrollo y creación de esta novela, que algunos han entendido como la primera moderna y otros de otras maneras, pero con la cual, sin duda, algo empezó en la historia de la narrativa o quizá algo ocurrió por una sola vez.

Tal como yo lo entiendo, lo que inventó Cervantes, laboriosamente, fue el artificio narrativo que les permitió a los autores que vinieron después, escoger una multiplicidad de maneras de controlar la máquina productora de historias. Pero, como suele suceder, el momento inaugural fue el más brillante de la serie y el de mayor riqueza estética. La más extendida y estudiada de estas maneras de control, por cierto, es el narrador personal y a menudo irónico de la novela moderna. Pero no es la única. He propuesto en otros años que Gabriel García Márquez en Cien años de soledad, utilizó para ese mismo objetivo el español latinoamericano en una multiplicidad de dialectos. Creo que toda la Primera parte del Quijote contiene profusas huellas de la invención cervantina, y más que nada, abundantes pruebas de la conciencia narrativa que fue desarrollando el autor hasta llegar a la plenitud que le permite libertades y desenvolturas deleitosas de leer en la Segunda. En mi lectura la huella más señalada, y quizá la más importante, es la que el propio autor quiso incorporar en el Capítulo IX.

Agrego que el aniversario de la novela ha sido probablemente la dichosa ocasión de una edición nueva (2001) al cuidado de Francisco Rico, sin duda definitiva, que viene a poner en un solo volumen el material narrativo de los doce tomos anotados que me alegraron hasta ahora en la póstuma de Rodríguez Marín de 1947, cuyas notas, sin embargo, seguiré disfrutando como una sabrosa conversación sobre la España del Siglo de Oro. 


\section{El capítulo IX}

Desde siempre me produjo extrañeza el Capítulo IX de la Primera parte. En mis lecturas tempranas no me gustaba la brusca interrupción del combate entre el Caballero y el Vizcaíno, ocasionada, como se sabe, porque junto con el Capítulo VIII se termina el manuscrito que hasta el momento seguía el que creíamos autor, quien ahora nos cuenta varias cosas: la pérdida de la fuente, el hallazgo casual del resto de la "verdadera historia" en el Alcaná de Toledo, pero en árabe y con un autor que se llama Cide Hamete Benengeli. Estos cartapacios originales, Cervantes (ahora personaje de la narración) los compra en medio real, y contrata su traducción con un "morisco aljamiado" que la completa en un mes y medio de trabajo, alojado en casa del encargante, al precio de "dos arrobas de pasas y dos fanegas de trigo". Padecí la interrupción y los datos que la componen y que son irrelevantes para la historia central, hasta que, ya estudiante de literatura, empecé a enterarme de lo mucho que los sabios tenían para decir sobre los componentes de ese Capítulo IX. Y con eso pasé de la desgana al interés y a la curiosidad. Sin embargo, los innumerables comentarios y explicaciones de los más mínimos componentes de la interrupción, leídos en notas, artículos y libros, no me hicieron más capaz de solucionar la extrañeza que me suscitaba el Capítulo IX. Adelanto que he tenido que leerlo desde el punto de vista de un contador de narraciones para terminar por ofrecerme a mí mismo una comprensión que me satisface y me sirve.

En otras palabras, en los muchos años que van desde las notas de Rodríguez Marín a las de Rico, no me han persuadido las lecturas que conozco de la aparición de Cide Hamete Benengeli más la del traductor, ni tampoco las lecturas de la participación de Sancho Panza en la aventura de los frailes de San Benito, primero, y en la conclusión de la del Vizcaíno después. Como todo el mundo sabe, en el Capítulo VIII arremete don Quijote contra dos religiosos a quienes cree raptores de unas señoras que van en un coche. Uno de ellos, por escapar de la acometida furiosa del caballero, se deja caer de su mula al suelo, y el otro escapa taloneando desesperadamente a la suya. Sancho se precipita sobre el fraile caído y se pone a quitarle los hábitos, que entiende ser el botín que a él corresponde de la batalla en que acaba de triunfar su señor. En eso llegan dos mozos de los frailes y evitan el despojo del caído con mucha violencia: "arremetieron con Sancho y dieron con él en el suelo, y sin dejarle pelo en las barbas, le molieron a coces y le dejaron tendido en el suelo, sin aliento ni sentido." Don Quijote, en tanto, está pidiendo a las señoras que ha salvado de los benitos raptores que regresen al Toboso a contarle la hazaña a su señora Dulcinea. Pero a un 
escudero de las señoras, el Vizcaíno (que se llama Sancho de Azpetia), lo enfurece la petición del caballero "salvador". Lo increpa, recibe respuesta, y deciden pasar de los insultos a los hechos. Sin embargo, la narración se corta precisamente cuando los dos contendientes van a trenzarse en duelo, porque según nos enteramos recién, el que narraba la historia no era propiamente su autor, y aquí se le han acabado los escritos donde encontraba su material. Comenta la nota de la edición de Rico: "la interrupción del relato para suscitar el interés del lector, recurso literario frecuente en los libros de caballerías y en poemas épicos, es utilizada por C. con intención jocosa". No me lo parece. Aquí el suspenso no es jocoso en absoluto. Al revés, detiene el desarrollo de una escena realmente divertida, compuesta por una de las frecuentes equivocaciones del caballero, más la codicia de Sancho, más el enrevesado discurso y la furia infantil del Vizcaíno. Lo que al lector se le suspende en el capítulo IX es precisamente la risa que le suscitaba el VIII: nadie puede reírse leyendo el casual encuentro de los cartapacios de Cide Hamete y los detalles de la traducción. ¿Por qué interrumpió la risa el autor? Me parece que por varias razones. La más ostensible: para poder continuar la narración y la risa. En efecto, cuando el cuento del duelo retoma su curso en el mismo Capítulo IX, vuelve tranquilamente la graciosa mezcla de sensatez y demencia del caballero, más las inocentadas codiciosas y divertidas de Sancho. Es decir, sigue la acción y vuelve la risa. Y en el Capítulo X, viendo a su amo victorioso, Panza "se hincó de rodillas delante dél y, asiéndole de la mano, se la besó" y le pidió que le diera el gobierno de la ínsula que acababa de ganar en esa "rigurosa pendencia".

¿Qué hubiera sucedido de continuar directamente la serie de acontecimientos jocosos del Capítulo VIII? Imaginemos que falta en el libro la pérdida de la fuente y también los pormenores del encuentro y traducción del original árabe. Hubiera ocurrido entonces, inmediatamente: el golpe del Vizcaíno sobre el hombro izquierdo de don Quijote, llevándole la armadura de ese lado y media oreja, lo que le ocasiona una furia descomunal y motiva el espantoso fendiente de su espada que no hiende al Vizcaíno, porque lo detiene la almohada en que se escuda, pero lleva fuerza suficiente para terminar con él derribado de su mula y echando sangre por boca, oídos y narices, lo que tranquiliza al vencedor y le permite mostrar su magnanimidad: acepta la promesa de las aterradas señoras de que su derrotado escudero se presentará ante doña Dulcinea para ponerse a sus órdenes. Todos estos acontecimientos no pueden haber durado más que unos pocos minutos. Pero entre el comienzo del combate y su término, el lector ha sido llevado al Alcaná de Toledo, muy lejos del escenario del combate, se ha informado de cuánto costó la traducción de los cartapacios árabes y del 
mes y medio que le tomó completarla al traductor. Por eso, cuando la novela regresa a la pelea, el lector no tiene ninguna dificultad para seguir disfrutando la historia, a pesar de la descomunal inverosimilitud de que Sancho, a quien le han arrancado a tirones las barbas y han dejado desmayado y sin respiración a patadas, se haya recuperado en unos segundos y esté apenas lastimado y ni siquiera piense en su daño. "Ya en este tiempo se había levantado Sancho Panza, algo maltratado de los mozos de los frailes, y había estado atento a la batalla de su señor don Quijote, y rogaba a Dios en su corazón fuese servido de darle vitoria y que en ella ganase alguna ínsula de donde le hiciese gobernador, como se lo había prometido". Y en efecto, viéndolo triunfante, le pide la ínsula de rodillas y con beso de vasallaje en la mano.

Sin el intermedio del Capítulo IX, se habría roto bruscamente el pacto de credibilidad que había establecido sólidamente el autor narrador con el lector en los ocho capítulos anteriores, y con eso se habría hecho imposible la continuación del libro. Todas las instancias previas al Capítulo IX se le han entregado al lector asegurándole que está disfrutando la verdad de la historia de don Quijote, que se contrasta con la patraña de las novelas de caballerías. Por lo demás, el libro entero, en sus dos partes, está dominado por la intención manifiesta de constituirse en el lugar en que reine la verdad cotidiana sobre la patraña caballeresca. El Prólogo de la Primera parte deja en duda qué quiere decir el juicioso consejero y amigo cuando juzga que "Sólo tiene [el autor] que aprovecharse de la imitación en lo que fuere escribiendo, que, cuanto ella fuere más perfecta, tanto mejor será lo que se escribiere". Y ya en la novela misma, el propio autor narrador introduce una precisión al considerar poco importante no saber cómo se llama realmente su personaje, porque "eso importa poco a nuestro cuento: basta que en la narración dél no se salga un punto de la verdad". Esto es lo distintivo que esta novela se atribuye a sí misma, la "verdad", palabra que precisa considerablemente la intención autorial, porque se constituye en el opuesto de la "patraña" caballeresca. La vuelve a usar el autor narrador cuando don Quijote cabalga narrando su primera salida y dice en estilo caballeresco que va "por el antiguo y conocido campo de Montiel". La voz narrativa confirma "Y era la verdad que por él caminaba". Creo que otros momentos textuales, especialmente el elogio de Tirante el Blanco en el escrutinio (I, vi), especifican esta "verdad": "por su estilo, es éste el mejor libro del mundo: aquí comen los caballeros, y duermen, y mueren en sus camas, y hacen testamento antes de su muerte, con otras cosas de que todos los demás libros de este género carecen". La intención que quiere controlar la narración está orientada por la oposición verdad/patraña, que sería largo especificar en 
detalle, pero cuyo contenido puede describirse gruesamente diciendo que el discurso del autor narrador más los diálogos de los personajes del mundo de don Quijote son los portadores de la "verdad", que claramente consiste en hacer que dominen en la narración las mismas objetividades que rigen las vidas humanas corrientes, mientras los dichos y hechos caballerescos de don Quijote portan la patraña. En eso se nos ha dicho que consiste el libro $\mathrm{y}$ eso es lo que estamos leyendo y nos produce disfrute literario.

Por lo tanto, la inverosimilitud de la historia de Sancho en el Capítulo $\mathrm{X}$ habría descalabrado la retórica que hasta ese momento sostenía el proyecto narrativo. El lector no habría podido tolerar que ya con un marco de instrucciones de lectura perfectamente establecido, se le contaran unos acontecimientos que lo destruían y que son relativos a uno de los dos personajes centrales de la obra, los que se mueven por el mismo mundo cotidiano en que se mueve el lector. De aquí la necesidad del artificio del suspenso.

Lo que me parece haber visto Cervantes al caer en esa inaceptable pérdida de la credibilidad del relato, es que cuando se trata de narrar, no basta con tener el propósito general de mantenerse en la "verdad". Hay que desarrollar maneras técnicas de conseguirlo. Y además, para el caso de este narrador irónico y humorístico, se puede (y quizá se debe) reconocer ante el lector implícito que la tarea no siempre se cumple, lo cual, paradójicamente, aumenta la eficacia de la intención narrativa de mantenerse en la "verdad", porque aumenta la complicidad risueña entre autor narrado y lector.

\section{La restricción religiosa}

$\mathrm{Al}$ autor narrador manifiestamente no le gusta la inverosimilitud de los libros de caballerías. Quiere contar sólo cosas que puedan ocurrirles a hombres como nosotros, no a semidioses ni a héroes míticos o fantásticos. Pero en este Capítulo IX queda claro que la tarea le empezó a resultar más difícil de lo esperado. Y esto, a nuestro juicio, porque se impuso otra restricción que no podía hacer parte de sus declaraciones expresas, pero que resulta en una conspicua ausencia en su narración. Estoy entre los que creen que el Quijote es un libro plenamente laico. No obstante haber sido escrito en el opresivo clima religioso de la España de la Contrarreforma, por un católico ferviente y militante, en el país más agresivamente católico entre todos los de Europa, las acciones del Quijote transcurren en un tiempo y un espacio cabalmente desacralizados. El calendario sacro que organiza el tiempo en el mundo católico, empieza cada año con el Carnaval, sigue con la 
Cuaresma, y culmina en el Viernes Santo, Sábado de Gloria y Domingo de Resurrección. Estas celebraciones mantienen la vigencia del tiempo sagrado en que vivían los españoles contemporáneos de Cervantes, y están completamente ausentes del libro. Es verdad que la acción transcurre en un solo verano y que eso deja fuera necesariamente la época de primavera en que se mueven esos hitos sagrados. Sin embargo, pienso que cabe preguntarse cuál pueda ser la razón novelesca de ese verano anormalmente largo en que el autor del Quijote obliga a caber las muchísimas aventuras del personaje. No pueden ser, creo, razones puramente estéticas, porque es fácilmente imaginable que un cambio de estación hubiera aumentado las posibilidades narrativas. $\mathrm{Y}$ una de las razones que se me ocurren es precisamente la determinación autorial de alejar lo más posible su ficción del calendario sacro: ni demasiado cerca de la Pascua de Resurrección ni tampoco de la Pascua de Navidad. El tiempo del Quijote no está regido por ningún dios. Es sólo el sucederse de los días y las noches, del dormir y despertarse, del cansarse por los caminos y descansar, del tener hambre, o calor o sed, del acontecer plazos humanos dependientes de promesas, o compromisos o locuras.

Ciertamente que por el libro andan religiosos de diferentes cataduras y que algunos de los personajes declaran ser creyentes, rezan, se persignan. Pero el mundo narrado no está organizado por la creencia, y las acciones de los personajes tienen motivaciones y resultados ajenos a la organización religiosa del mundo.

Habiéndose prohibido el autor narrador permitir que la religión organizara su mundo, había renunciado con eso a un elemento de control sobre las acciones ficticias que venía usándose desde la Antigüedad y que si bien no eliminaba la posibilidad de que ocurrieran acontecimientos imposibles o improbables en esas imitaciones, la aminoraba grandemente. Agréguese a esto que poniendo las acciones bajo la tutela de los dioses o de un dios único, se habían constituido sólidamente géneros con reglas objetivas que facilitaban la empresa de los autores. Las narraciones que forman el Antiguo Testamento, por ejemplo, están dominadas y facilitadas por el objetivo general de presentar la relación entre Jehová y el pueblo de Israel. El mundo de la épica griega y la tragedia está también organizado por las dispersas y a veces contrapuestas voluntades de los dioses olímpicos. El de la épica cristiana, por la voluntad de un Dios único que les da sentido y límites a las acciones del héroe. Al renunciar, pues, a la presencia de la religión como organizadora de su mundo ficticio, el autor narrador del Quijote perdía una posibilidad probada y codificada de controlar su narración. 


\section{La limitación moral}

Esa limitación implícita que se pone el autor narrador no es la única. También renuncia a la posibilidad de hacer que sea la moralidad quien presida la presentación de las acciones. Es posible que esta renuncia provenga en buena parte de la otra. Que por no admitirse la influencia expresa de una religión en el mundo narrado, eso impida también que se utilice la moral para dar sentido a los objetos y acciones ficticios y determinarlos. Como sea, es un hecho que el autor narrador del Quijote presenta a sus personajes con manifiesta neutralidad. Tanto, que cuando por un momento olvida esta restricción y toma partido, desconcierta al lector, como es el caso en que sin ningún motivo literariamente justificable, se arranca con un vituperio contra el "grave eclesiástico" que parece ser director espiritual de los duques (II, xxxi).

Desde el lado de la recepción del libro, apunta a esta misma ausencia de un control moral de las acciones, el hecho de que hayan sido necesarios siglos de lectura y de evolución ideológica para que se especule acerca del carácter moral de los personajes, y que recién hoy se dude de que sean efectivamente buenos algunos que desde siempre fueron aceptados como modelos de bondad o a lo menos, nunca se pusieron en duda sus motivaciones. Es el caso entre otros del Cura, a quien ya no todos entienden como portador de sensatez bondadosa, o de Anselmo (el personaje de "El curioso impertinente"), cuya posible tendencia homosexual nunca antes se postuló. Pero se piense sobre ellos y sobre algunos otros lo que se quiera en el terreno de los valores éticos, parece indudable que el Quijote no está elaborado a partir de una concepción moral de la realidad que les dé sentido a las acciones de los personajes. Antes a la inversa, todas ellas producen una atmósfera de ambigüedad valórica que les da la misma problematicidad y espesor existencial que tienen las acciones de los hombres reales.

\section{Una novela que acepta regirse por el orden religioso y moral}

Otro libro, el Guzmán de Alfarache (1599), prácticamente contemporáneo del Quijote, me parece documentar lo que ocurría cuando un autor se proponía narrar vidas de hombres como nosotros, es decir, ocuparse de la verdad cotidiana, sin las restricciones que se impuso Cervantes. El éxito de esta novela picaresca fue inigualado en su tiempo. Tuvo 23 ediciones antes de 1605. Se lo considera la novela picaresca paradigmática, la culminación del género que había iniciado medio siglo antes Lazarillo de Tormes (1554). 
Lo mismo que Lazarillo, el Guzmán tiene la intención de presentar ante el lector la vida cotidiana de hombres como nosotros. Y lo consigue. Pero frente a la básica bondad que trasparenta la narración de Lázaro, el Guzmán está impregnado de amargura, cinismo, desesperanza, conciencia incesante del carácter pecador de los hombres, es decir, conciencia postridentina. Y en lugar de la refrescante crítica a los malos clérigos que tenía Lazarillo, el Guzmán ofrece una visión en que el bien está representado por algunos eclesiásticos (por ejemplo, el bondadosísimo cardenal que acoge en Roma al pícaro y trata, sin éxito, de llevarlo a la buena senda), pero que son un fenómeno excepcional en el mar de suciedad moral en que consiste el mundo narrado. El libro ha sido leído por algún crítico como teniendo su fundamento ideológico en la relación entre la gracia y el libre albedrío. Y cualquier lector puede ver por sí mismo que el autor narrador organiza el mundo a partir de la religión católica postridentina, contraria esencial del espíritu renacentista y de su esperanzada y dichosa visión religiosa y moral del mundo. El peso restrictivo de la ideología española de la Contrarreforma es lo que le sostiene al sevillano su narración, que él subtituló "Atalaya de la vida humana". En otras palabras, a diferencia de Cervantes, que quiere librarse de los constriñentes tradicionales que pesan sobre la narración, Alemán consigue el control de la suya poniendo en obra la opresiva estructura ideológica de la Contrarreforma, muy ajena al espacio libérrimo del narrar cervantino. El caso es de notarse, porque Alemán y Cervantes son rigurosos contemporáneos, y sus libros también.

\section{Efecto de la autolimitación cervantina}

Desde hoy parece indudable que estas limitaciones que se autoimpone el autor narrador, la de no utilizar la religión como sentido y marco de su relato ni tampoco la moral, tenían que producirle problemas que nunca habían acuciado a los autores con la severidad que a él.

No me parece que la dificultad que se le presenta a Cervantes al narrar los acontecimientos relativos a los frailes benitos, al Vizcaíno y a Sancho, provenga solamente de que en el Quijote aparezca el propósito de narrar con "verdad" la vida cotidiana de hombres que sean como nosotros, ni más altos, ni más bajos. Lo que a mi entender le produce las dificultades es que sin la religión y la moral, se pone en juego una característica de las imitaciones literarias de acciones que ya había aparecido en el horizonte del presentar acciones ficticias casi dos milenios antes, con Aristóteles, pero nunca con tanta persistencia ni tanta fuerza como al imponerse las restric- 
ciones con que se autolimita el Quijote. Por cierto que tales restricciones pueden verse a mejor luz como liberaciones. Sin los dioses y la moral para constreñirla, la máquina narrativa puede funcionar, se diría, plena, libremente.

Creo que un exceso de esa libertad ocasionó las dificultades de la narración que determinaron la elaboración del Capítulo IX. Sin los constrictivos externos de la religión y la moral, que fueron los mayores - aunque no los únicos - en las narraciones anteriores al Quijote, la máquina narrativa arriesga producir imágenes o secuencias de imágenes inaceptables por disparatadas, o por incoherentes o por radicalmente incomprensibles.

El Capítulo IX, pues, guarda huella de un problema que le acentuó la modernidad a las narraciones y que, hasta donde sé, Miguel de Cervantes fue el primer escritor en encarar y solucionar con cabal conciencia de lo que hacía, pero que ha seguido hasta hoy apareciendo frente a los narradores en trance de escribir y frente a sus críticos. $\mathrm{Y}$ esto porque cada narrador moderno tiene que volver a planteárselo cada vez que se propone empezar un nuevo libro, y todo crítico serio debe también adoptar decisiones de lectura relativas a lo mismo cada vez que se aboca a entender una nueva novela.

El problema proviene de una característica del discurso narrativo que hoy día puede enunciarse fácilmente, pero que en tiempos de Cervantes sólo una intuición portentosa habrá permitido enfrentarla y solucionar los problemas que les ocasiona a los narradores. Puede enunciarse de la siguiente manera: las secuencias de objetos y situaciones en que consisten las narraciones no tienen en sí mismas componentes que permitan controlarlas internamente de tal manera que produzcan sólo imágenes y secuencias de imágenes que estén regidas por la lógica y la experiencia.

La razón no es muy fácil de ver, pero es simple: a la narración le es imposible el uso pleno del adverbio "no", ese mismo que se utiliza en lógica o que, transformado en el número 0 , usan los matemáticos. Por cierto que la palabra "no" es de frecuente ocurrencia en cualquier narración, pero es rara en el discurso del narrador y jamás tiene valor cabalmente negativo. Es decir, siempre implica una afirmación. Contar que un personaje no hizo algo, implica que debió haberlo hecho o que se temía que lo hiciera o que regularmente lo hacía, o alguna otra cosa que el lector pueda representarse como existente en el mundo narrado. De la misma manera, describir un objeto o un personaje negando alguna característica o estado, sólo puede tener sentido para indicarle al lector que le importa saberlo si quiere entender cómo es el objeto o el personaje y qué lugar ocupa en el desarrollo de la acción. La carencia de "no" pleno se ilustra en lo que se cuenta de Alejandro Dumas, 
que inventó una vitrina donde iba poniendo figuritas que representaban a cada personaje y sacándolas cuando morían, con lo cual solucionó el riesgo de que volviera a ocurrirle lo que le había sucedido una vez, que fue reincorporar inadvertidamente a la acción a un personaje que había muerto en algún momento anterior. Es decir, que en el acto de estar narrando, ni siquiera para el autor histórico de una novela el "no" radical que significa la muerte funciona plenamente.

Se habrá notado ya que al caracterizar así la narración, viene a resultar semejante a la conocida concepción de Freud según la cual las leyes de la lógica, especialmente la de contradicción, no son válidas para el Ello, que en él pueden existir juntos impulsos contradictorios sin neutralizarse ni excluirse y que no existe allí nada asimilable a la negación. Esta característica la experimentamos todos diariamente en los sueños. Allí nos encontramos con personas que identificamos como las mismas que conocemos en la vida vigil, pero sabemos al mismo tiempo que son otras, es decir, el principio de identidad no rige el ámbito onírico. Aparecen en él gentes muertas mucho tiempo atrás, es decir, la negación no existe. Volamos tranquilamente por nuestros propios medios, lo que es contrario a las leyes de la experiencia. Somos testigos de francos dislates como que el demonio (entidad en quien no creemos) se transforme en una damajuana que ladra. El inconsciente no está regido por el principio de identidad ni por el de contradicción ni por el del tercero excluido, porque no conoce la negación plena, indispensable para que ellos tengan vigencia. Si en un sistema significativo no existe el "no" cabal, equivalente al cero matemático, ni la identidad puede existir, ni la contradicción, ni puede desaparecer nada que alguna vez estuvo en el sistema. Si se quiere introducir constrictivos que permitan imitar creíblemente el mundo en que estas realidades existen, hay que inventarlos, desarrollar algún artificio técnico, que puede ser tan simple como la vitrina de Dumas o muchísimo más complejo.

\section{El problema de imitar acciones no es nuevo}

Que esta característica de las imitaciones de acciones humanas mediante el lenguaje no es nueva y no depende de que los autores quieran contar asuntos relativos a las vidas cotidianas, lo prueba el conocido pasaje de la Poética de Aristóteles en que se les muestra a los que quieren hacer tragedias la necesidad de que atiendan a la posibilidad y la probabilidad de lo que presentan. El famoso pasaje $60 \mathrm{~b} 26$ de la Poética se había leído siempre como que Aristóteles habría dicho que era preferible presentar en la 
tragedia una acción o una cosa probables aunque imposibles más bien que unas posibles, pero improbables. Este juicio no sirve en esa forma para leer nuestro Capítulo IX. Recién en 1967 Gerald Else, en su definitiva lectura del pasaje, produjo un sentido que creo hubiera sido del gusto de Cervantes. Según Else, el consejo a los poetas (hacedores de tragedias, es decir, de argumentos) es que han de manejar cosas o acontecimientos - en cuanto pueden ser posibles o imposibles - de manera que los materialmente imposibles en sí mismos se hagan probables al lector o espectador, y que los materialmente posibles en sí mismos, no se hagan improbables. La idea sirve cabalmente a la comprensión de nuestro capítulo.

\section{La invención de Cide Hamete}

No parece que pueda caber duda de que justamente cuando se le ocurrió la aventura de los frailes benitos correlacionada con la del Vizcaíno, Cervantes vio claramente lo problemático de escribir un relato con las características que él lo quería. Enfrentado a dos ocurrencias narrativas suyas que debe haber hallado graciosísimas y considerado coherentes con su concepción de sus dos personajes principales, se dio cuenta al mismo tiempo de que no podía presentárselas al lector en la secuencia que la narración requería, porque había ocurrido algo extraño. Tanto don Quijote como Sancho mostraban en la aventura de los frailes el carácter que el lector ya conocía y que a través de sus diálogos y acciones es la fuente de mucha de la gracia de leer. En efecto, el caballero vuelve a mal entender un acontecimiento caminero según el habitual esquema que le hace aplicar ideas caballerescas a sucesos de la vida cotidiana, y ataca a los frailes. Sancho confirma su carácter codicioso y crédulo en el intento de desnudar al fraile caído. En la pelea con el Vizcaíno, don Quijote vuelve a mostrar su natural colérico y su demencia caballeresca, y Sancho, otra vez, el suyo, codicioso e ingenuo, al pedir la ínsula. Lo que no funcionó, sin embargo, fue la credibilidad de la secuencia, porque el intento de despojo del fraile requería una solución rápida y violenta y la que conocemos funcionaba bien. Por otro lado, el gracioso pedido de la ínsula al término del combate con el Vizcaíno, era el remate natural de esa aventura, pero entre ambos acontecimientos simplemente no había tiempo suficiente para la recuperación verosímil de Sancho.

Lo que produce asombro es que un autor de esa maestría haya dejado la secuencia tal como la conocemos y haya intercalado el Capítulo IX como único disimulo de la incredibilidad. Se conduce como si quisiera ostentar lo precario de su solución. Dos "autores" son creados en ese capítu- 
lo, Cide Hamete Benengeli y el traductor. Se conserva el narrador autor que ya conocíamos. He aceptado alguna vez que este último es el narrador de la novela moderna, y propuesto que su función es hacer aceptable la historia de don Quijote a los lectores. La introducción de Cide Hamete, a mi juicio, es la personificación de esa potencialidad de disparate que la falta de "no" pleno le ocasiona como una incesante amenaza a toda narración. La capacidad humana de producir analogías de la vida cotidiana mediante palabras me parece una de las mayores riquezas simbólicas del hombre, pero es, en último término, imposible de controlar del todo.

Que Cervantes se daba clara cuenta de lo que estaba haciendo, se ve, primero, en el mismo Capítulo IX en el comentario del autor narrador: "Si a ésta [historia] se le puede poner alguna objeción acerca de su verdad, no podrá ser otra sino haber sido su autor arábigo, siendo muy propio de los de aquella nación ser mentirosos". En otras palabras, el origen de esta narración es contradictorio con la intención autorial de contar una historia "verdadera", porque puede producir y produce contradicciones, quimeras, incoherencias, imágenes increíbles. Desde el lado de la patraña, se confirma la condición no verdadera de las analogías literarias de la realidad, pero aquí ironizando el descubrimiento con un chiste. A don Quijote "desconsolole saber que su autor era moro, según aquel nombre de Cide, y de los moros no se podía esperar verdad alguna, porque todos son embelecadores, falsarios y quimeristas" (II, iii). El caballero teme también, pero desde el lado de la patraña. Lo altera la posibilidad de que el moro lo haya presentado eróticamente indecente. Desde ambos lados del mundo del libro se repite, pues, la misma idea: la más señalada característica suya es la de inventar embelecos, falsedades, quimeras. Lo cual es un claro reconocimiento de que las analogías conseguidas por medio del lenguaje simplemente no son definitivamente controlables. La diferencia es que el narrador autor atribuye a eso la posible falsedad de la narración, mientras que don Quijote teme no haya mentido el autor en punto a su conducta erótica impecable. La doble significación de la palabra verdad en el mundo cotidiano y en el de la patraña es una aplicación maestra de la inseguridad de los significados del lenguaje en el territorio de los juegos de la imaginación, que son los de la vida humana. La declaración del autor narrador ocurre justamente en el momento en que la mantención de la gracia de cada acontecimiento destruía la credibilidad de su relato y contradecía su intención de mantenerse en la "verdad". El pensamiento de Aristóteles en la lectura de Else funciona, pues, aquí de maravi1la. Hay un narrador autoencargado de hacer creíbles las acciones que cuenta el libro, pero una intención significativa superior a la suya advierte a través de sus dichos que esa credibilidad no puede esperar mantenerse 
sobre la base de una comprensión lógica de la palabra "verdad". Simplemente no hay manera de evitar que se encuentre en ella alguna cosa que contradiga la lógica que los lectores aplican cada día (principios de identidad, realidad, tercero excluido), o las leyes de la experiencia (la mortalidad, las limitaciones y necesidades del cuerpo, la forma de las relaciones humanas, etc.) o, cabe agregar, que nunca contradiga las objetividades de la cultura en que se produce y se lee. Es decir, hay aquí huellas claras de que el autor Cervantes se dio cuenta en este capítulo de que la tarea era sumamente difícil.

El desarrollo posterior del libro parece probar que terminó por considerarla imposible. Según los manejos textuales que ocasionó la mayor incoherencia del libro, el robo y reaparición del jumento de Sancho, parece haber razón para creerlo. Según las notas de Rico, en la segunda edición de Juan de la Cuesta, Cervantes hizo esfuerzos por corregir la incoherencia, pero con no muy buen resultado. Sólo en la Segunda parte, diez años después, aceptó plenamente la insoluble mendacidad del moro y en el Capítulo IV hizo a Sancho contar el robo del burro utilizando una idea narrativa de dos Orlandos, es decir, de dos libros patrañescos. No bastó, pues, la atención vigilante del autor narrador para imponerle la "verdad" al moro.

Creemos que la dificultad sigue hasta hoy, y que quizá la historia de la novela pueda entenderse como el interminable esfuerzo por encontrar técnicas de control sobre la máquina narrativa (sobre el moro mentiroso) para conseguir que sólo produzca análogos impecables de la vida humana. Hay que admitir, sin embargo, que no son pocos los novelistas que en alguna medida han renunciado a conseguirlo: Voltaire, Virginia Wolf, Selma Lagerlöf, García Márquez, Borges, Bioy Casares, Cortázar, entre otros.

\section{La paradoja del narrador de vidas humanas}

Decimos que en el Capítulo IX hay huellas de un comienzo: el de la conciencia del autor de que está haciendo algo nuevo, afectado por una dificultad que no había advertido hasta entonces. Repitamos que esa dificultad se vincula con el momento en que Cervantes quitó a los dioses, los héroes y su predicado social mayor, la moral, el control de la máquina narrativa para narrar vidas de hombres como nosotros. Se dio entonces cuenta de que necesitaba objetivar al narrador y darle atributos. Pero se le introdujo en el sistema un elemento extraño, que advirtió y reconoció en la Segunda parte: no consiguió hacer "verdadero" el acto mismo de narrar. Lo prueba Sancho comentando que le han dicho que el libro los tiene a él y a la 
señora Dulcinea de personajes "con otras cosas que pasamos nosotros a solas, que me hice cruces de espantado cómo las pudo saber el historiador que las escribió". A lo que don Quijote responde haciéndose cargo del problema de la "verdad" literaria y solucionándolo con una descripción: "Yo te aseguro, Sancho ... que debe de ser algún sabio encantador el autor de nuestra historia, que a los tales no se les encubre nada de lo que quieren escribir" (II, ii).

El Capítulo IX contiene, a mi entender, el momento en que se identifica al narrador que había de heredar la novela moderna y en que al mismo tiempo se advierte que la máquina narrativa, suelta de sus anclas religiosas y morales, ha de estar para siempre buscando acceso al puerto de la lógica y la experiencia, al que jamás podrá llegar definitivamente, pero hacia donde siempre estará dirigiéndose.

\section{El problema de imitar vidas humanas con palabras siguió}

Digamos para terminar que una mirada, por ejemplo, a los carnets con que Flaubert trataba de dar solidez realista a sus narraciones nos dicen que el problema del Capítulo IX siguió actuando, y determinó que ese autor en trance de escribir La educación sentimental, consultara tratados de medicina para describir la enfermedad del hijo de la señora Arnoux, tomara cuidadosas notas de los terribles acontecimientos de París en el verano de 1848 en vistas a escribir su libro y que se documentara extensamente sobre las posibles maneras de acceder a París desde Fontainebleau en esos mismos días para describir el viaje de Frederic. Todo lo cual dice que este autor realista se dio trabajos de tipo científico, semejantes a los de un historiador, para controlar su narración. En otras palabras, la controló siguiendo el modelo de la ciencia. No del todo, sin embargo. En una nota de Pierre-Marc de Biasi a la edición de Classiques de Poche (2002), nos enteramos de que C. Gothot-Mersch señaló que, si se toman en cuenta las fechas de los acontecimientos históricos reales que la novela da como contemporáneos de la acción, resulta que Flaubert cayó en la enorme incoherencia cronológica de hacer durar dos años el embarazo de Rosanette, la amante de Frederic.

Pero también explica cosas más significativas para un interesado en escribir narraciones. Por ejemplo, la creación de una entidad ficticia descendiente del autor narrador y que ha recibido enorme atención crítica. Ciertamente que Henry James estaba enfrentado al mismo problema de controlar la narración cuando inventó su "lucid reflector" o "central intelligence", que resume su método de representar el mundo narrado mayormente a través de 
los ojos de un personaje. Pero ciertamente que tampoco lo consiguió. La disputa entre los críticos, por ejemplo, sobre el sentido de Otra vuelta de tuerca, centrada en la confiabilidad nula o máxima de la institutriz narradora no ha terminado, que yo sepa, en décadas de desentendimientos. Y otro tanto pasa, aunque en menos grado, con casi todas sus narraciones y sus "lucid reflectors". Cervantes vio bien, el moro autor es para siempre mentiroso.

\section{Observaciones finales}

Mucho empezó en ese Capítulo IX de la Primera parte del Quijote. Y me parece que desde ahí puede comprenderse mucho de lo asombroso y lo nebuloso de la portentosa novela. Quiero terminar estas consideraciones con una observación que pertenece a las que yo mismo desapruebo como "disparos al infinito". Quizá no es la primera novela moderna esta maravilla de Cervantes. Pero ciertamente que, como notó hace muchos años Wolfgang Kayser, en ella nació el narrador personal. Y también nació alguna otra cosa que hizo a Henry Fielding, uno de los reconocidos creadores del género, poner en la portada de su primera novela, "Written in imitation of the manner of Cervantes". Sin embargo, lo que a mí me sacude a veces, en alguna de mis relecturas, es la sospecha de que esta inauguración de la modernidad narrativa en el Quijote, lejos de la religión y la moral, puede ser un fenómeno único, al que cada vez menos puedan aplicársele las nociones que caracterizan las narraciones, y que sólo por un afán historicista desmedido le aplicamos ideas de evolución o precursoría. No soy religioso, pero admiro algunos santos cristianos. Y creo que algunos (San Francisco de Asís, San Juan de la Cruz) son acontecimientos únicos en la no muy feliz historia de la devoción humana. Es sabido, por ejemplo, que San Francisco no era, propiamente, franciscano, que vivía de acuerdo a la estrictez de su propia regla, tolerado al margen de su congregación. Quizá el Quijote es, en medio de la opresión ideológica terrible de la España de la Contrarreforma, una explosión tardía de creatividad lingüística, que conserva toda la libertad, toda la inmanencia dichosa que el Renacimiento ofreció al hombre. 